\title{
The Fight Against Poverty in Algeria and China
}

\author{
Ahcène Boukhelfa
}

As soon as I arrived in China, I was immediately struck by the magnitude of the movement that I perceived as a powerful engine driving all of Chinese society. I felt like I was in a country in action driven by a strong dynamic pushing it to always move forward.

Every day a new achievement, an important scientific or technological discovery, a technical progress in this or that field were announced. In short, we felt that we were living times that were out of the ordinary. We told each other that we had a strong feeling of living history, of being in history that was being made.

Moreover, indeed, we witnessed a truly extraordinary event when the Chinese government announced the end of poverty in China.

By the end of 2020, the 1,113 villages in the 52 districts that were still considered poor in China were finally lifted out of poverty. After eight years of hard work, nearly 100 million people in poor rural communities, by China's current standards, had all been lifted out of poverty.

In 1978 , extreme poverty affected $80 \%$ of the country. However, since then, a combination of rapid economic growth and an effective anti-poverty policies has eliminated extreme poverty.

In the past 42 years, marked by the reform and opening-up policy implemented in 1978, more than 700 million Chinese have emerged from poverty, contributing to more than $70 \%$ of global poverty reduction efforts.

China's achievements in the fight against poverty over the past 40 years are simply remarkable.

A historic and unique act has just been accomplished. Since China has existed, that is to say for more than 5,000 years, this is the first time in the long epic of the Chinese people that poverty has been defeated and that there are no more Chinese living in

\footnotetext{
A. Boukhelfa $(\varangle)$

Embassy of the People's Democratic Republic of Algeria to the People's Republic of China, Beijing, China 
China who suffer from this disease. To experience a moment of this importance and intensity is truly exceptional.

This is a huge contribution China has made to the global development agenda, including the Sustainable Development Goals that the United Nations aims to achieve by 2030 .

It was with great enthusiasm that I accepted the invitation of my friend Dr. Huiyao Wang, President of the Center for China and Globalization, to deliver a speech about "The fight against poverty in Algeria and China: Cooperation actions and similarities", in front of the China Public Relations Association.

Here, I will recount the thoughts I shared during that speech.

I was honored to have the opportunity to share my views on the poverty alleviation experience of the People's Republic of China in my capacity as Ambassador of Algeria, and as a foreign observer of China's development from the inside.

I had been living in this great country for almost five years, during which and I had the opportunity to visit many parts of China.

Without any hesitation, I would say that the most amazing thing I witnessed during my stay was how fast the development projects were implemented and how much the living conditions of Chinese people had improved since I'd arrived in 2016.

I was incredibly pleased to have the opportunity to applaud the significant achievements made by the People's Republic of China in recent years in its fight against poverty, enabling it to achieve its first centennial goal of building a moderately prosperous society by the end of 2020 .

I am fully convinced that, given the demographic, economic, and diplomatic weight of the People's Republic of China in the international scene, that the eradication of poverty in China is likely to have a direct positive impact on economic and social development throughout the world.

Global poverty is perhaps the greatest issue in the world today. 24,000 children die every day around the world from poverty-related causes. The annual amount needed to end world hunger is USD 30 billion. The benefits of reducing poverty go beyond humanitarian efforts and can help with a country's economic and strategic interests.

China has made great progress in the fight against poverty because its leaders have mobilized the nation around clear policies, resources, realistic goals, and strict discipline. China's experience in eradicating extreme poverty should serve as a reference for others.

Since the implementation of the policy of reform and opening-up, the vast majority of Chinese people have been lifted out of poverty and China has become the first developing country in the world to achieve the UN Millennium Development Goals.

Indeed, the fight against poverty has always been a high priority for the Chinese government. China has been committed to eradicating poverty since the adoption of its policy of reform and opening-up. It has gradually adjusted its poverty reduction targets in line with economic development and has set up special agencies to standardize and institutionalize poverty reduction efforts:

- In 2013, President Xi presented the strategy of a "focused fight against poverty" in the provinces; 
- On May 12, 2014, the Anti-Poverty Bureau of the State Council published the Implementation Plan for the Establishment of a Targeted Anti-Poverty Work Mechanism;

- On December 2, 2016, the Council of State published an anti-poverty plan covering the period of the 13th five-year plan (2016-2020), which serves as an action guide for local governments to combat poverty and is an important basis for the relevant departments to elaborate special anti-poverty plans.

The number of rural poor in China decreased from nearly 700 million at the end of 1978 to zero at the end of 2020, as shown by data from the National Bureau of Statistics of China.

President Xi stressed at an internal symposium held in March 2020 and at the 73rd session of the World Health Assembly in May 2020 that when the task of eradicating poverty is completed at the end of 2020, China would have achieved the poverty eradication objective set out in the United Nations Agenda 2030 for Sustainable Development ten years ahead of schedule, which is of great importance both for China and for the world, as no country in the world has ever managed to lift so many people out of poverty in such a short period of time.

The United Nations Development Program (UNDP), whose main mission is to support the Sustainable Development Agenda 2030 and to implement the Sustainable Development Goals (SDGs) by 2030, applauded China's development over the past decades, which has deeply impressed the world. China is the first country to reach the poverty reduction target set in the UN Agenda 2030 for sustainable development.

According to the UNDP, China has adopted a comprehensive poverty reduction strategy with multiple approaches, which is a good example of China's promotion of human development and is an example other countries can learn from. UNDP officials have said that China's achievements in fighting poverty are unprecedented in terms of scale and timing and that countries can learn from China in terms of how to make their economies develop in a more systematic and organized way, which is in line with UN MDGs.

The UN predicts that it will be difficult to achieve the poverty reduction goals of the Agenda 2030 for Sustainable Development, due to the negative impact of the COVID-19 pandemic on the world economy and on developing countries in particular.

African countries, for example, have made positive progress in promoting sustainable economic and social development in recent years, but the continent is still far from achieving the goals set out in the UN Agenda 2030 for Sustainable Development. Most of the world's poor live in Sub-Saharan Africa, making this region the center of global poverty governance.

The rate of poverty reduction in developing countries other than China has been comparatively slow, and the number of poor people is ever increasing. For example, the number of people living in extreme poverty in Sub-Saharan Africa increased from 278 million in 1990 to 413 million in 2015, representing more than half of the world's poor. 
It should be noted that China has always made a great contribution to poverty reduction and development in Africa. Trade and investment between China and Africa have boosted Africa's economic development, improved its economic situation and, to some extent, reduced poverty. Similarly, China announced in 2015, at the FOCAC Johannesburg Summit, the implementation of a Sino-African poverty reduction plan.

Algeria and China are connected by a traditional friendship and fruitful cooperation since the establishment of diplomatic relations in 1958. Mutual political trust, economic partnership, and humanitarian exchanges between the two parties have certainly contributed to the development of both countries and their fight against poverty.

I will not give a detailed account of individual cooperation actions, but I will mention some examples that have a direct bearing on the fight against poverty:

I. In 1963, Algeria received the first Chinese medical mission dispatched

abroad, a mission whose composition is still regularly renewed to this day, which has allowed access to health care to a significant number of Algerians, especially in less developed areas. Algeria now has enough doctors, but the two countries continue this action of cooperation as it represents a symbol of traditional friendship;

II. Bilateral cooperation has also been expanded in the fields of science, technology, and space, particularly with regard to the launch of the first Algerian telecommunications satellite (ALCOM SAT 1) from China on December 11,2017 . This satellite is an important tool that provides internet and radio television coverage in disadvantaged areas;

III. Chinese operators have strengthened their presence in Algeria and participated on Algerian development programs, especially in the field of infrastructure (highway and housing construction), as they were granted different public development projects for more than USD 70 billion over the last 20 years.

The participation of Chinese companies in development programs in Algeria is reciprocally beneficial, both for the Algerian side and less developed areas and for Chinese companies and workers.

The fight against poverty, which is an important mission for all developing countries, has always been at the center of Algerian government policies.

The Algerian state has made considerable efforts to improve the situation and living conditions of the population in all areas, particularly in housing, urban planning, health, education, employment, and others.

However, several villages and localities are still woefully underdeveloped, manifested in the lack of access to water, electricity, roads, health care, Internet and cell phone coverage, housing, and jobs. These underprivileged localities are called "gray areas" that the government is working to ameliorate.

The development of gray areas has been one of the most important commitments of Algerian President Abdelmadjid Tebboune since his election in December 2019. This commitment aims to ensure equal opportunities to both the inhabitants of rural areas and residents of urban centers. 
This political will is demonstrated by the appointment of a Special Counselor to the President of the Republic in charge of following up on the issue of "gray areas", as well as by regular instructions to the various ministers and provincial governors to boost local economic development through the modernization of administration, the opening-up of disadvantaged and marginalized areas, the connection of industrial and agricultural areas to energy and the strengthening of small and medium enterprises in order to increase employment opportunities and add value to the national economy.

An accurate and detailed inventory of the concerns and needs of the populations living in the gray areas has been carried out in order to determine priorities and develop an emergency program to make up for the delays in development.

An amount of USD 1.5 billion was allocated in 2021 to implement 48,000 local development projects for the benefit of 15,000 gray areas covering 9 million inhabitants.

These projects aim in particular to address the urgent and necessary concerns of these populations in terms of access to drinking water and energy, opening-up access, promoting schooling and transport conditions, and establishing conditions and mechanisms to create productive activities in these regions.

Since the improvement of gray areas covers a broad range of issues, I will focus on five aspects: access to water and energy, access to healthcare, road infrastructure, employment, and Internet coverage.

Regarding access to water and energy, the Algerian government insists that supplying water and electricity to gray areas is an absolute priority for development programs.

For very remote and landlocked regions that cannot be supplied with water by pipelines or connected to the existing electricity networks, the authorities have recommended guaranteeing supplies of water by using tanker trucks equipped with solar energy kits.

Importance is also given to the need to speed up electrification and natural gas supply projects in gray areas. The Algerian Ministry of the Interior, Local Authorities and Territorial Development has identified more than 8,000 gray areas nationwide lacking electricity and gas supplies. The government has adopted a program from 2020 to 2024 to connect more than 140,000 homes to electricity networks and 370,000 others to gas.

Concerning access to health care, the Algerian Ministry of Health has focused on the necessary management of health needs in gray areas in order to ensure the health services needed by their populations.

In-depth studies are underway to examine the best ways to ensure health services in these areas and the mobilization of the human and material resources needed to respond to health requirements.

In addition, multidisciplinary medical caravans for the benefit of people suffering from chronic diseases in gray areas are regularly organized. These caravans include mobile clinics in internal medicine, cardiology, and ophthalmology, as well as biology laboratories to carry out various biological examinations. 
Similarly, the healthcare sector's approach to gray areas is to provide them with renewable energy such as solar power.

With regard to road infrastructure, the Algerian government has made major efforts to open up gray areas through several programs whose results are already beginning to be felt.

Over the last few months, the Algerian government has mobilized significant budget allocations through a number of development programs dedicated in particular to the opening-up, development and maintenance of rural roads, communal roads, and forest tracks.

A good number of these roads have been completed, thus contributing to the opening-up and revival of economic activity in several regions of the country. The road projects were implemented thanks to the expertise acquired by Algerian public and private companies specializing in public works.

With regard to employment, several programs have been carried out to promote economic activity in gray areas. A national campaign to identify the opportunities and needs of gray areas across the country was launched in September 2020 for the creation of microenterprises to diversify the national economy.

This campaign aims to identify the opportunities and needs of the gray areas across the country for their exploitation by the inhabitants of these regions through the creation of microenterprises to boost development.

Measures have been taken, for example, to strengthen entrepreneurship and the spirit of innovation among project leaders in the fields of tourism and handicrafts.

These measures provide support for project holders in the field of tourism and handicrafts and enable them to take advantage of training programs, encourage the creation of microenterprises to contribute to sustainable local development, particularly in the southern regions, the highlands, and gray areas.

Regarding cell phone and internet coverage, the Algerian Ministry of Post and Telecommunications insists on the need to connect all areas to the national network, as these services have become indispensable for their citizens, just like water, electricity, and gas.

Cell phone operators are called upon to respect their commitments to serve the citizens, and the government is making considerable efforts to connect isolated areas to the Internet, in coordination with the Algerian Space Agency.

I would like to reaffirm my willingness to work with Algerian and Chinese Experts, scholars, think tanks, and other institutions, in order to exchange experiences and expertise regarding public governance, including the fight against poverty. 


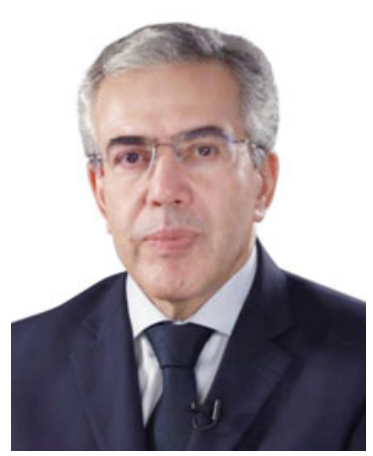

H.E. Mr. Ahcène Boukhelfa is the ambassador of the People's Democratic Republic of Algeria to the People's Republic of China. He has been the ambassador of Algeria to China since 2016. Mr. Boukhelfa has rich experience in foreign affairs. He started his career in the Ministry of Foreign Affairs of Algeria in 1978. He was the ambassador of Algeria in Burkina Faso, followed by Argentina and Uruguay and Paraguay with residence in Buenos Aires (Argentina). Mr. Boukhelfa graduated from the National School of Administration in 1978 and he was also Associate Professor of "Strategic and Prospective Analysis", "Conflict Management and Forward Planning" and "Propaganda and Foreign Policy" at the National High School of Political Science from 2000 to 2004 and from 2010 to 2014.

Open Access This chapter is licensed under the terms of the Creative Commons AttributionNonCommercial-NoDerivatives 4.0 International License (http://creativecommons.org/licenses/bync-nd/4.0/), which permits any noncommercial use, sharing, distribution and reproduction in any medium or format, as long as you give appropriate credit to the original author(s) and the source, provide a link to the Creative Commons license and indicate if you modified the licensed material. You do not have permission under this license to share adapted material derived from this chapter or parts of it.

The images or other third party material in this chapter are included in the chapter's Creative Commons license, unless indicated otherwise in a credit line to the material. If material is not included in the chapter's Creative Commons license and your intended use is not permitted by statutory regulation or exceeds the permitted use, you will need to obtain permission directly from the copyright holder.

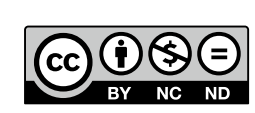

